\title{
Investigation on the Status quo of College Students' Career Selection
}

\author{
Cuilian Ai, Yongmei Zhang, Jianxue Duan
}

Baoshan College of Traditional Chinese Medicine, Baoshan 678000, Yunnan, China.

\begin{abstract}
With the expansion of colleges and universities, the market employment situation is becoming more and more serious. A large number of college graduates are facing major challenges in choosing employment. Under this background, career selection is the key factor that guides college students' successful employment. Establishing a correct view of career selection can help college students improve their self-awareness, clarify career planning, and improve employment concepts, etc. so that college students can smoothly graduate and find satisfying jobs. This article aims to analyze the problems of college students' career choice through investigation and research on college students' career choice, and puts forward improvement strategies in combination with the current employment situation, in order to provide some help for college students' career choice education.
\end{abstract}

Keywords: College Students; Current Status of Career Selection; Problems; Countermeasures

According to the Ministry of Education, in 2019 there are 8.34 million higher education graduates across the country, which hit the record. The issue of college students' job selection and employment has become a hot topic of social concern. At present, there is a common phenomenon in the job market. The difficulty of college students' employment and the lack of talents in various sectors of society exist at the same time. This is a paradoxical situation. This phenomenon is fundamentally analyzed and has a direct relationship with the current college students' incorrect career choice. College students' career choice determines their professional orientation and behavior, and plays a very critical role in the process of college students' career and employment. In order to solve the market employment contradiction and promote the employment of college students, it is needed to give correct guidance to the problems that arise in college students' view of job selection and help college students achieve successful employment.

\section{The status quo of college students' career selection}

With the development of social economy, college students> career choices have also undergone changes. In the 1970s and 1980s, college students paid attention to social status. In the 1980s and 1990s, college students focused on job stability and their specialty. In the 21st century, they highly value the «two-way selection, independent career selection» employment mechanism. With the influence of money concepts and utilitarian ideas, students now can make a variety of choices before employment, such as graduates, civil servants, and going abroad to continue to heat up. Among them, there are also a small number of independent entrepreneurs. At present, college students pay more attention to the material economy.

Through the survey data, we find that contemporary college students have certain concerns about their future employment and are not optimistic about the employment situation. Most college students think that the salary and benefits are low and there are too few suitable jobs. Lacking social relations makes it difficult to find jobs. Some students are persistent in finding professional positions, preferring to postpone work without employment, and others. Students are affected by family values, and parents' decisions are also one of the factors that influence college students' career choices. From the point of view of the relationship between the lack of social relations and employment difficulties, there is a certain deviation in the understanding of social relations among college students in the mentality of job selection.

Copyright (C) 2020 Cuilian Ai et al

doi: 10.18282/le.v9i6.1311

This is an open-access article distributed under the terms of the Creative Commons Attribution Non-Commercial License

(http://creativecommons.org/licenses/by-nc/4.0/), which permits unrestricted non-commercial use, distribution, and reproduction in any medium, provided the original work is properly cited. 


\section{Analysis of college students' career choice}

At present, in response to the situation of college students' employment, the author conducted a sample survey of 1706 college students of different colleges, different majors, and different grades. After investigation and analysis, it is found that some common problems exist in college students' view on career selection, as follows:

\subsection{College students pay too much attention to material interests}

In the survey on the factors that pay attention to job selection, $18 \%$ of people prefer salary and benefits, and $27 \%$ choose a good working environment. From the analysis, we can see that college students pay more attention to work units with high wages and a good environment. Career requirements are not the first choice of positions and professional counterparts, personal abilities, future career development, but the satisfaction of material spirit.

\subsection{College students lack the spirit of hard work and self-hardening}

There are also objective reasons why college students are currently labeled as "having grandiose aims but puny abilities" by society. Some college students have a superior family environment and lack social practice experience. They do not think about progress, love ease and hate work, and are reluctant to try grass-roots work. They are afraid of suffering and being unable to withstand work pressure. According to the survey, $28 \%$ of college students prefer to choose economically developed cities to work, only $9 \%$ are willing to go to the grassroots level, and only $2 \%$ are willing to join remote areas in need of talent (no $2 \%$ data).

\subsection{College students' lack of personal subjectivity in choosing a career and being too concerned about their surroundings}

Some college students are influenced by their parents, relatives, friends, and classmates when they choose a career. They listen to the opinions of others around them and pay attention to the opinions of those around them. They think that it is not suitable for college students to do grass-roots after graduation. Some college students are too dependent on their parents. When choosing a career, they ask parents for suggestions, lack the subjective awareness of independent career selection, and lack the ability to analyze, solve, and judge problems.

\subsection{There are deviations in college students' career choice values}

Most college students have deviations in their ideas about career choice values. College students believe that the primary purpose of employment is to solve their personal livelihoods and achieve economic independence. The realization of personal social values and the development of their own interests and hobbies are put as secondary factors. A small number of students choose to work out of pressure from parents and relatives in the family, not personal will. Based on the analysis of the reasons for the deviation of college students' career choices, the problem mainly stems from the rapid development of social economy, the transformation of political culture, and the fierce competition of market talents. It affects the change of college students' ideology and concepts and distorts their life value orientation.

\subsection{College students lack career planning}

Most college students lack awareness of their personal career planning, and they are very confused about the direction of their future career development. Some college students even hold a "muddle along" attitude and have no substantive plans for future work. The proportion of students that really have clear goals and career plans is very small, only $8 \%$.

\section{Educational countermeasures to improve college students' career selection}

\subsection{Change college students' career selection}

Colleges and universities should establish a career guidance course for college students, guide students to establish a correct outlook on career selection through course learning, give students instructions in terms of employment skills, employment rules, career planning, professional ethics, etc., and guide the employment situation and employment policies of college students. It is necessary to guide college students to change their original wrong career selection ideas, formulate reasonable personal employment expectations, and allow college students to actively adapt to the current employment situation and participate in the competitive environment of the job market with a correct attitude.

\subsection{Efforts to improve personal abilities}

The four years of college are the last educational opportunities for college students to work hard to learn professional knowledge and improve personal comprehensive literacy and professional skills, to have a greater 
advantage to participate in employment competition. College students should pay attention to their professional learning and practical activities, and acquire more abilities from learning and practice, such as interpersonal skills, practical skills, organizational skills, communication skills, problem-solving skills, etc, which is helpful for them to adapt to the social environment faster.

\subsection{Change your mind and recognize yourself}

Facing the severe employment situation, college students should change their minds to clearly know themselves to put down their attitudes and give priority to employment. They shouldn't be greedy for pleasure, nor blindly pursue the material economy and working environment, demand a high salary, and hold unrealistic ideas. They should cultivate the spirit of dedication and hard work, improve themselves on the career path, take the initiative to petition to remote areas in desperate need of talents, and contribute their own strength to the overall development of the national economy. Therefore, they can also receive a better self and plan for further goals for future career development.

\subsection{The concept of cultivating "versatile talents"}

Some undergraduates emphasize too much on professional counterparts, which hinders the employment of undergraduates. This is an era of competition. In fact, the principle of recruitment of most employers is still focused on two aspects of personal ability and comprehensive literacy. Whether it is the professional counterpart is not the primary prerequisite for recruitment, so college students do not have to worry too much. The social division of labor is getting finer and finer, and the requirements for college students to be more versatile are getting higher and higher. Even if the major and the job are not completely in line, college students can learn more knowledge and work experience from the job, which will benefit the college students in their personal development. Therefore, colleges and universities should focus on cultivating college students' overall literacy and all-round skill development, to cultivate college students' innovative and pioneering consciousness, so that they can adjust their career selection in a timely manner, thereby expanding the scope of employment and enabling college students to actively choose jobs.

\subsection{Establish the concept of independent entrepreneurship}

Colleges and universities should enhance students` cognition of entrepreneurship. College students have a strong sense of innovative thinking and are easy to accept new things. They have great advantages in employment and entrepreneurship in todayss new advanced technology fields and industries. Therefore, to cultivate college students awareness of self-employment, they should fully understand the national inclusive policies and regulations related to college students' entrepreneurship. The school should help them to stimulate entrepreneurial confidence, establish the concept of independent entrepreneurship, and achieve the purpose of entrepreneurship to promote employment.

\section{Conclusion}

College students' career selection is the cornerstone of deciding employment development, helping college students to establish a correct career selection concept. It is the focus of college employment guidance training to ease market employment pressure, promote social and economic development, and help college students actively participate in employment. Therefore, colleges and universities should pay full attention to the cultivation of college students' career choices, pay attention to the shaping of students' life and social values, strengthen the cultivation of students' hard work spirit, and create a good employment guidance atmosphere for students, so that college students can find their personal career goals and rational position employment expectations, establish career planning, and smooth their employment road.

\section{References}

1. Yuan T. Research on the status quo and countermeasures of college students' career selection ideas. Changjiang Series 2018; (19): 223.

2. Li W, Wen H. A survey of college students' career selection and educational countermeasures: Taking Jiaxing College as an example. Young writers 2013; (4): 224-225.

3. Xiu F. Research on education countermeasures of contemporary college students' career selection concept [dissertation]. Liaoning: Dalian Maritime University; 2015.

4. Sun S. The current situation and countermeasures of college students' career selection in Heilongjiang province [dissertation]. Heilongjiang: Harbin Normal University; 2016. 